究考研たら野かわ学は著和一

の察究。、にれた、、作十つわ

領さのこ奥位たつ経多が五がが

域れ展の井置とて済数出年、国

でる開点のゔ言み学の版奥に 注よ過に都けっら、業さで井お

目う程つ市らてれ行績れあ復い さにはい研れもる政がてる太て る思、て究る、が学、かこ郎試 べお奥はは作過、、発らとにみ きれ并、、品言睍建表今はよら 業る自後社でで㺺築さ目、つれ 績が身に会あは袋学杂におてた み、瑟学るな都都きたいて著都 ら琾活る研とろ市市たるくさ研 れ帒史。究にう諭計。ま異れ究 な都とたか注。に画そで論たの い都研しら目こ学う、の居な わ市究か出しのよなし都な現か け論のに発た著てどた市い代で での道、しい作て、業研と大最 は刊程わたと㔔都数績究こ都む 行を㤎思社市多注のろ市注

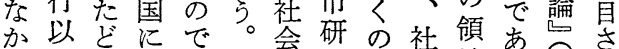
前るおは乙学究研会域万有秃 た沈汀、かのの究学にう斐る こ都たるなし研扉分䧉お地いこ閣業 の研で市っが分開に理ての昭積

都研がと三寄市程過しの作 市究研戦次年る研社。究去たな品 究な前第代よが学確業績に刊 はさににをう、の績には行 れお都迎飞活分追にも、 一たい市えな発野跡は注示れ つて研てり、にに目唆る のはは究か、おおたーしに以 潮、、にら次こいう定た富前 流い都対の々なてえのいむ とえ市しことおは究限と業発 ななをてと業れ、、界思績表 るいめ研で績て今 研がうもさ に。ぐ究市加い日究認。多れ は戦り者つ発る、の現数た 、前、息た表が多現ら代諸 い多注。さ、角㓪れと見業 たあ数意昭れ社的状るい出績

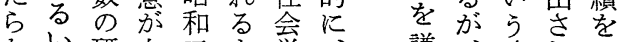
ない研向三よ学、謙、時れた かは究け十う者ま虚わ点るど つ戦者ら年に热たれに。っ た戦にれ代な都、検わ立こて 都中るるもつ市多詩れ立のみ 都中っょ後た研次守はて機る 市たてう半の究元 ベ、考会と 研小集ににはに的 究て中ない関に はは的った昭心 き研究会、 で究る、そ あ過を竞え

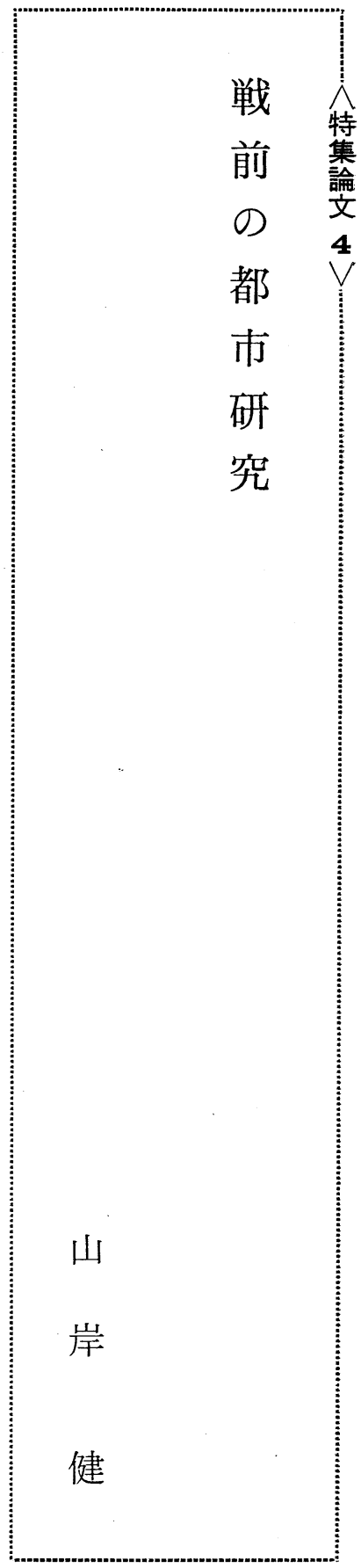


研く究っれ主め浮れう前指い戦なれ社うにもる、な異 究なをてて軸戦るかる。の摘ら後いた会。は、をむ のいみもきを前べび。点業さべのでの学し、少けのる 報がる、年しのき上戦檢績れき都あにのば社なれに観 告、と都よて、わでが前がをる論市ろ対研し会くど終点 なア、市り、があっの不緻場点研引究ば学なも始や どメ問研はお国々て業十密合㤎究。て領指者か、角 が、題究、こにうく績分飞它、のそ、域摘のっ鮮て度 、カののはなお。るをな検あ少主れ都でさ注た明しか おの指領るわけ か検た討るな要で市はれ意。なまら こ都摘域かれる も討めしがかなも研、て が戦問、試 な市、ににて社し守に、、ら課、究家き向前題、み わ研市認注い会れる、そ都ず題戦の族たけに意体ら

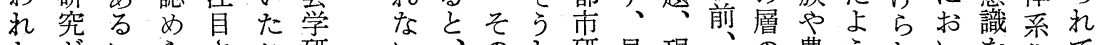
たがいらさこ研いる。研見現戦の農うれれを化て

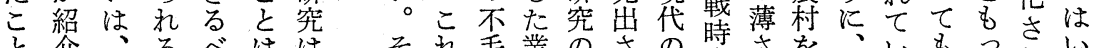
と介、るべはは もさ提よき明、 あれ言う成ら都 たた た たり、と思が、゙研 昭わま机たると 和がつるとがは 時国た。充別 代の都戦断従な の 都市前片 来研 多市論の的究 様のも 都で論 領 な調少市は評域 都查な研あさを

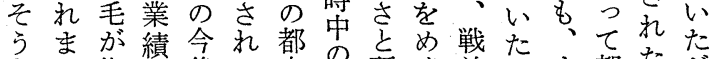

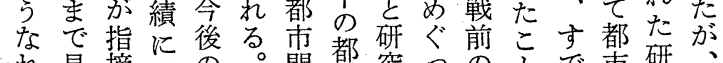
れ見摘学の。問都究つのとで市研、 ば落さぶ発戦題研のて研は究研究そ わさ势姿乵前生究貧充究計都を績ら れれき勢期都活をと夆況憶市お都ま わてたを劣市課たをしを憶とこ、多 れきよとる研題と認たみさいなまく のたうりた究のてめ塐るれてうここは 認二にための原みざ績なて閔たと面な散 識面思々注型型るるがらよ題研に散 改、思戦㤎交得ら域者な的

常がスつロ考おどえる自郊の戦題と市市都正み究市

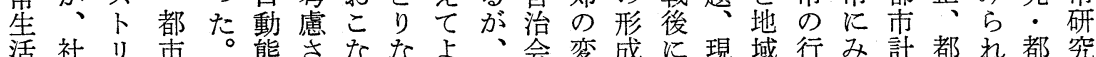

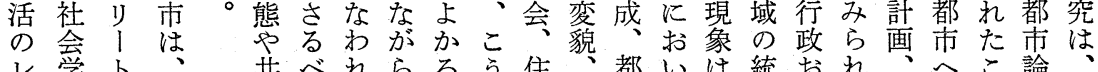

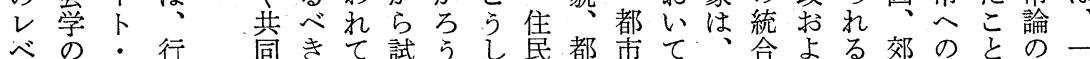
ル研パ政生もいみ的運市生は戦吕び社外人背貫 で究タの活のるら戦現動化活、後国財会交口、景し

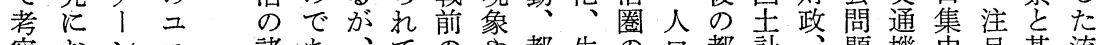
察おン 諸あ、てのや都生の口都計、題機中目基流 さいなッ形ろかい都論市活拡の市画い威、乙底れ れてど、態う。よた市点防環大過研なわ都の過たにで てはと、の。う。研は㴔境、密究どば市整大いは考 き、い目都な戦究、な問都、のに、、の備都。、察 た都っ常察市問前のす它題市過背わ都生と市そ次さ の市た生市研題の多でを再疎後た市活郊のれのれ では、活、い究は研くにめ自開現にるの様外形はよる

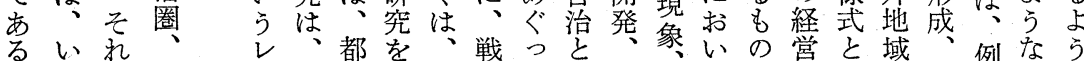

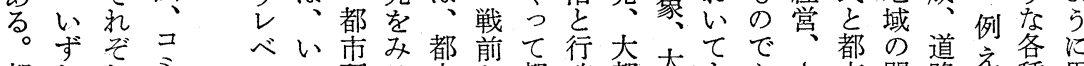
都れれミルつ研る市か都政都大都むむ市開埴え路思 市にの二にの究々とら市市都認るら生発拡ばのお 生せ観三主時の、農注研権周市め。に活、張市改れ

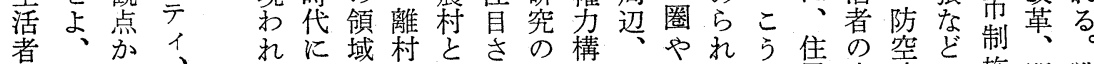
の わ 生 研 社 生わ研 社 形れさ態 れ れ 世 てあに問い氺造あメるし偊生防に施問戦 きっお題うて開、るガのた組活災も行題前 たていの文いが町い口で改織意問みか、边 のもて考脈たみ内はポあ革の識題ら市現都

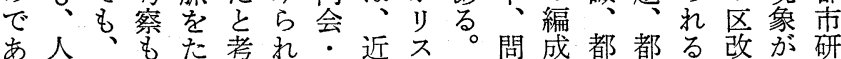




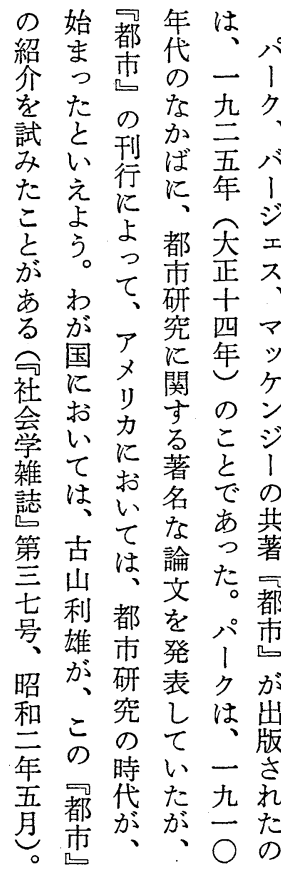

幸らはで向注都式で活究指つ生そ い、、あは目市、あ論戦に摘て活れ で今どろ、さ研都り前求さ研組ぞ あ後のうわれ究市、都のめれ究織れ るのよかがよにのこ市都らるさ、の 研う。国うは人うの市れでれ日地 究に都の。、間し社研るあて常域 の素市社ヨすにた会究。万き生・ 出描研会 Iで関も問は㧧孞活 発さ究学口にす大題、学、゙ 点れのにッると戦、エで とる領お方人研の都口後戦 1 み 方の域けお間究関市論の前りら 向でをるよ生が連問、都のアれ にあ中都び態、に題市市都なる つろ心市ア学多おと政研市ど生 いうと研メの面いい論究研が活 てかし究リア的てっ、の究、者 考。てに力プに、た都源にわの え先みどに口な都線市流つが生 る学るのみ、さ市を計のい国活 このとよらチれ社た画多ての意

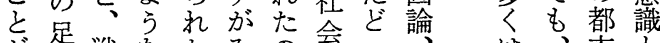
で跡䇳なた影社らで都て文は市市研行 ぎを前影社らで都て交者 戦う究㗢 るた日章たる市察論前し者朵 など本与のこ。のさ、のたたタ らり社え研々戦生れ都都点ち! ばな会た究も、前活る市市がにン

市うす運たに注一八九のと六纂誌調二年と昭於紹ま と。る動。関自六、世領で奥言矛等查頁題和け介た のま研な奥すさ巻九紀域あ井号東第法と月し三る批 出た究ど井るれ二、初をっが、京五にし、て年社評磯 会、ににの研るー一期中た究昭市分関てこ紹公会を树

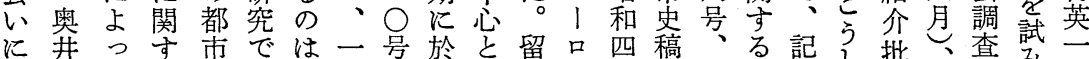

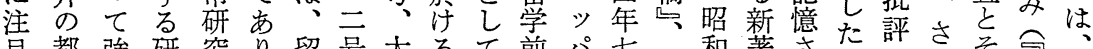

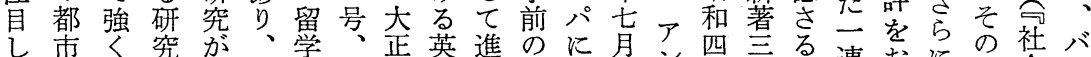
た研導に、そ前大十国め奥留に父年篇心連おに文会!

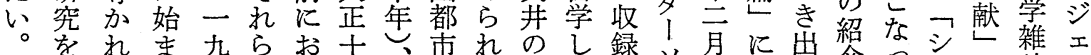

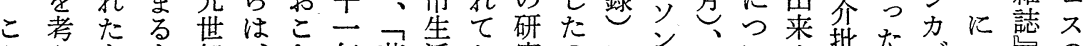
うえもを紀、な年英活お究のにン磯い事批だ゙っ㤎の しるののイ次わし国のりははも都树てと評かにい第转 た場ででギ々れが田二、都社大拉市のもいい、都て言都

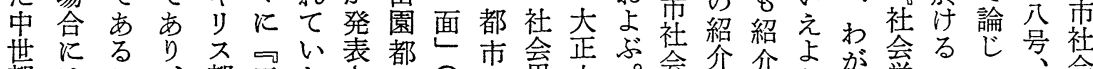

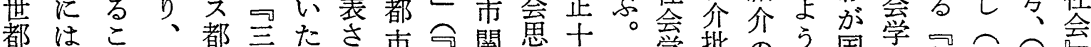

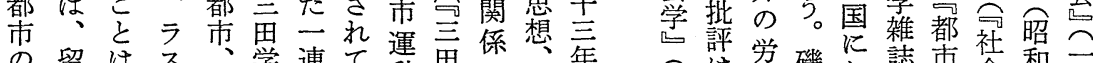
の留はス、学連て連思の、年、䙎労磯お誌市社和二

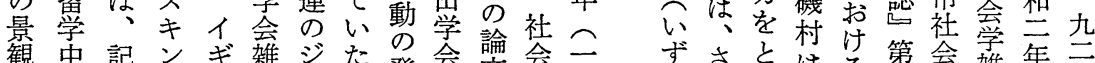

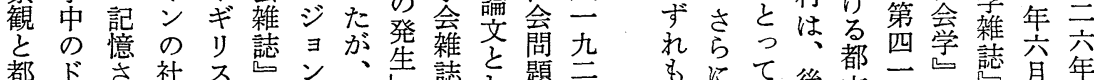

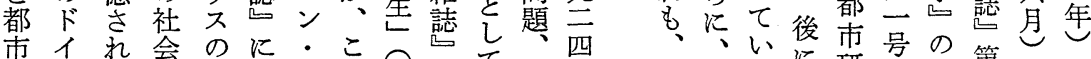
の

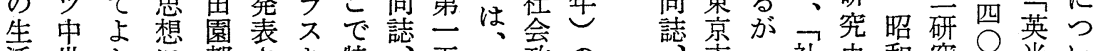
活世かに都さキ特、五、政の、市 社史和究号米い 空都ろ関市孔ンに第巻十策こ第編同会の二し方にて 
がの立通でれ二とれ七第奥のれれ紀ス論昭一後の間 とて、社場じあ、形考て年兰井都こた都キ和考に形に

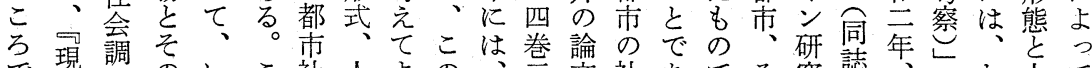

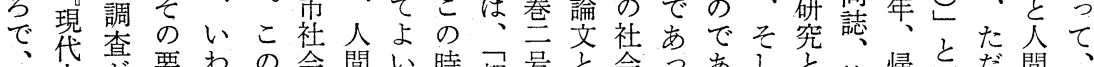

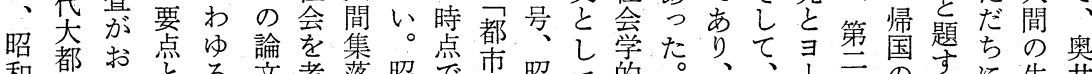

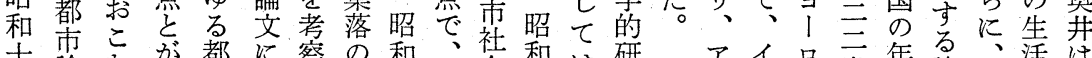
十論なが都に察の和、社和は研、アイ、卷年る論、活は

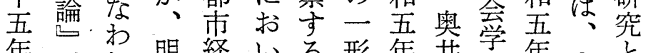
まが年琞経いる手式の型年年年ま喜 で刊都か論はが、前都考一ず竞 行市にや、か一記市落九問

都さのさ都都り定論研祭言都題 市さの的市市と文究心都に 研れ理た問のし地にの同年市関

究た論の題定て点お理誌眮高

はで亥で義、渭い論訫が題る

都あ查る区調あ市現て的第指二眚

市さと。別び意れ、組六さ教と

社た方そさ本識た都み巻れ察い

体の後質が集市が落はるさ点 系後た都関注落は明号さ言点

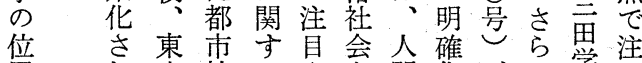

置和京社るさ主間化がに学自

沙や会考れ規定さ発、会さ

けや鎌学察た定住れ表昭雑れ

メギッ巻で論交の、

リリパ言あ文市関コ カ不都号発発連ミ 都園研が、登都性三 市都究発羿れ市着テ 研究苍登に発登眼へ 究りド袁はき生すの る合智たさ男虫よ在 に点世奥に会ドに自 いに都奥に雑イな覚

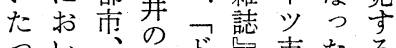
たいてィ都だ第制たる のかギ市ッ起でい はたリ研都二源あた ち不究市巻にるり 㷌ぐ住究号関帰都 後ら世ラ序方国市

てにるや基こもあ論い昭集第て昭まり盆にる・量称そ い注。施ゔのいる文て和集六の和たっ蚠分も区管ささ

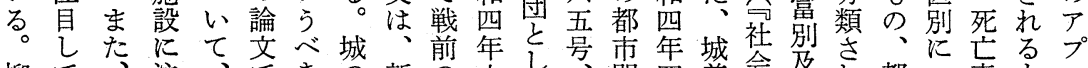

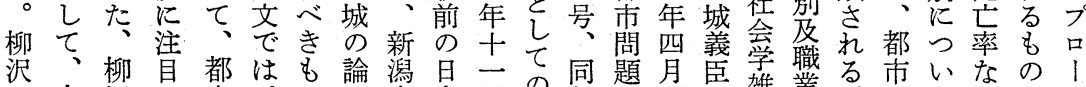
沢大柳目都はも論潟日一の同題月臣学雑業る市いなの1

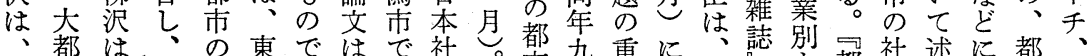

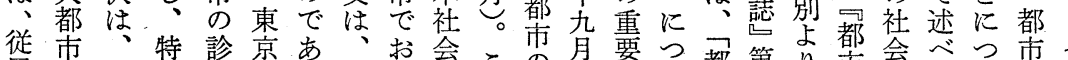

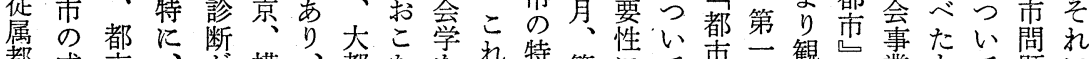

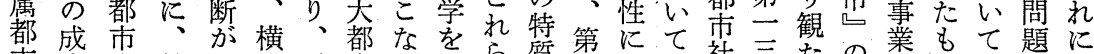
市立登教な浜バ市わ語ら質兵つ論社会たの紹にの論の題に

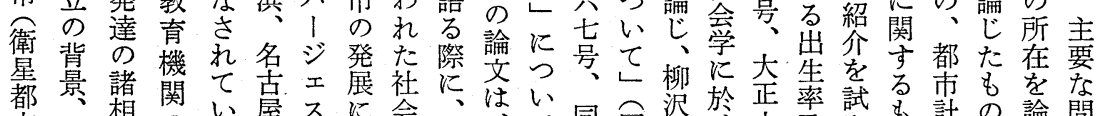

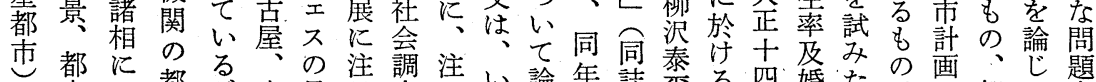
の市つ都が京見自查自い論年誌爾る四婚たの画、都た題 形近い市、都解しにさずじ士第は主年桇古出関市も都た

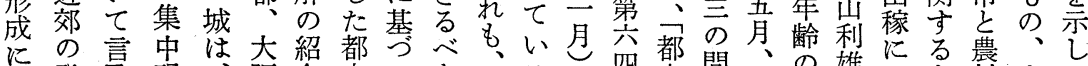

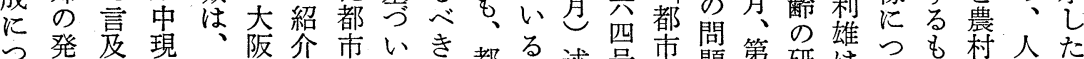

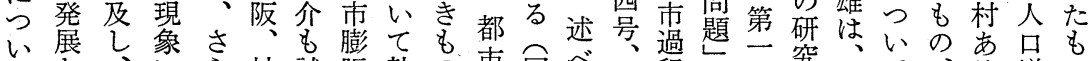
てな、にら神試脹執の市同べ、昭程同五究々て、无堌の

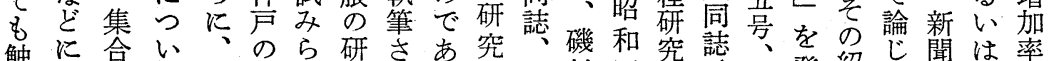

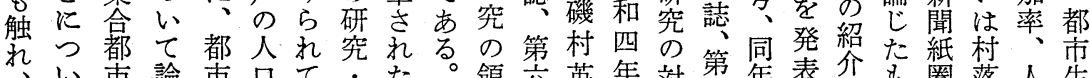

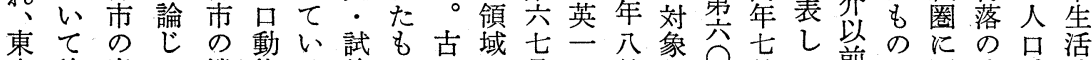
京論出て 機態る論の山に号は月号月て前な関比受論

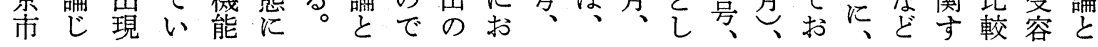


接注っ生実や都かこしれ帯びめてて論成所生なみのと 近目こ活態バ市らのて、資に流お文果と活わら論々 し、うのに、の利論、都李、別りにを規にれれ文の よ、しいもジ集益文都こなの種個、おと定つてるに近 うそたず注エ団社を市のど年々な人いりしいいがお郊

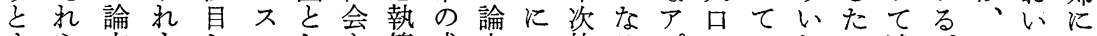
すら文をしししと筆成文つ的るプのはれこ述。こてみ るのにが、著てしす員にい增考口都、てと柳うはら 姿研つ、家作のてるるお打察 1 市東執も、沢し、れ 勢究いこ族も特の時職いも采集京筆あ都はた都る で業ての解、質現点業て、東、が中市さる市、考市人 あ績共論体用を実で変は考京試示の内れ。を第察生口

り索通文現い把のは花、察市みさ実昼たこ個一の活現 活にで象ら握都、磯が内られ数夜都の人次合の象 ま用認はにれし市磯社村なにれ、に人市論が的铜諸に たしめ、注てょへ村会はさおた集基口論文間集に相関 なら考意いうとは移、れいの団亏゙のとは断団、や禾 各がれ察をるとい、動り、てでとい差し、なのパ都る 種らるさ向。試う共し人都みあして異てアき関、市考 の、これけ磯み、同に市らつて都にも又刺係ク生察 統さとたて村たそ社つキ生れたの市関、リ激がの萿を 計らはのいはのの会いン活る。都をす注力に弱都者試 資に、でる、で進とてのの銀そ市考る目に浴ま市なみ 料、外㐫。婚あ展しも著諸行うの察考さおしう論どて をわ国つ都姻り過て言作断集し特守察れけつてのにい 活闰研た市お、程の昂を面中、質るがよるるい紹関る

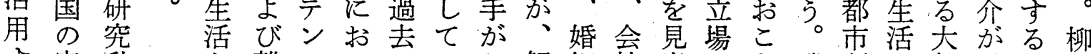
す実動離二いののいか解姻社出にな磯研守都、考沢

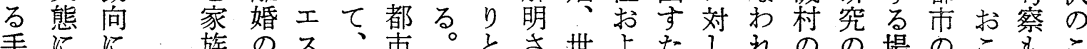

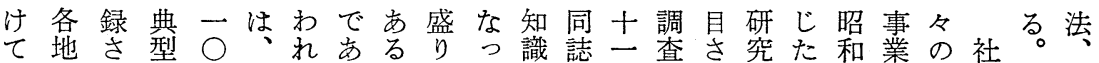
い域れ的号鎌たり、場た階年㕣れとこ調事会社

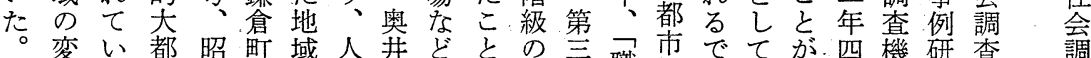

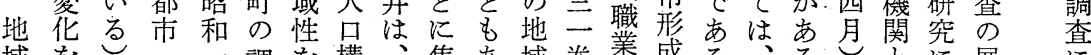

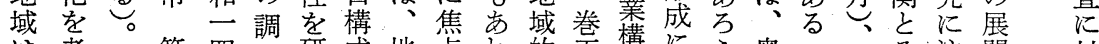
は鋯奥第四查研成地点独的吾成関う奥合古々注開 対

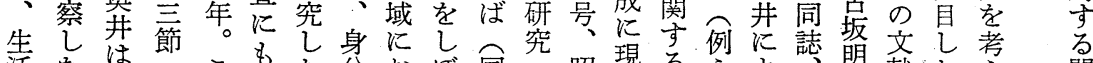

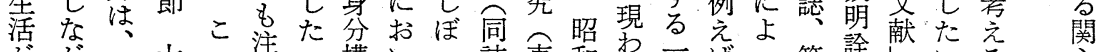

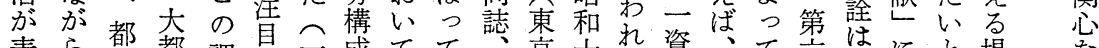

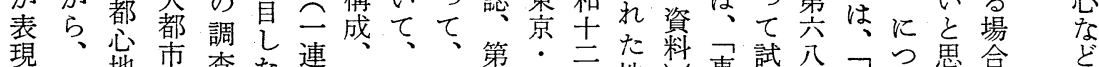

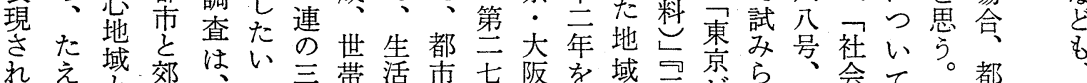

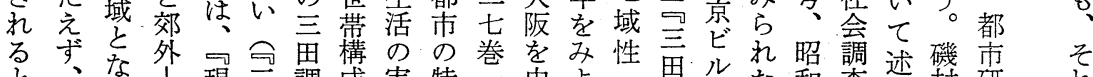

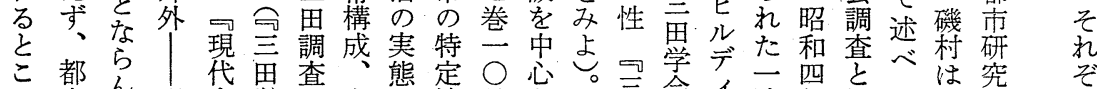

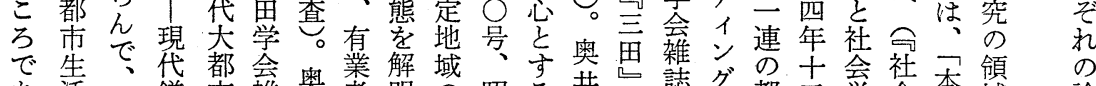

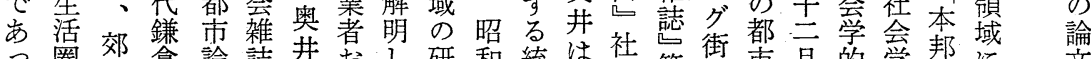

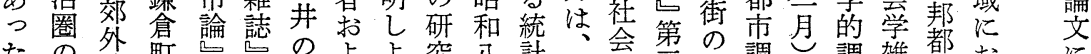

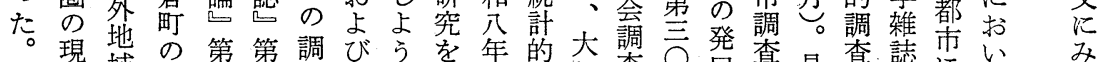

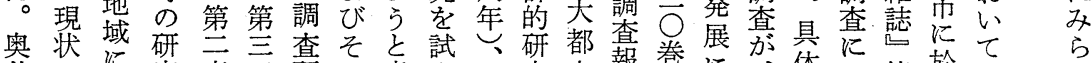

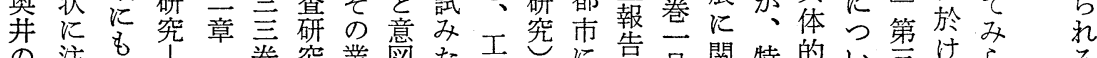

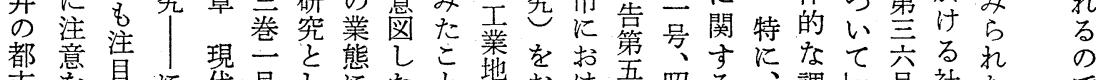

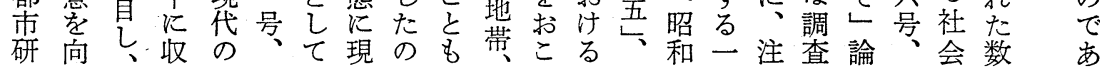


究とたす独に甲光論圏

こ圱で性い市はて関市

ろ一活あ々がてに、おすを

で面圈っの、述於新りるの

都らした。生明だ柏論も

市みう新態かこ調䌐会にに

机視聞度にと查巻拿\&?

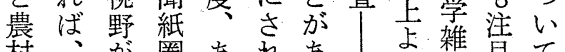

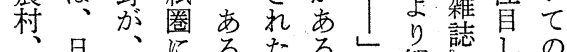

都常展ついるた が公観管た研

市生望いはで、社た第い究

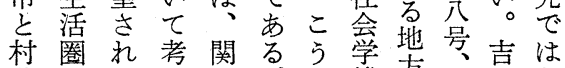

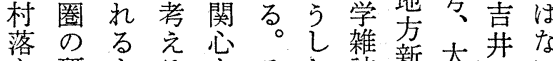

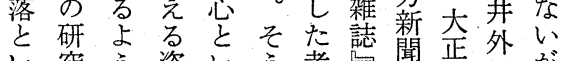

心究 う姿いう考等の十成正外

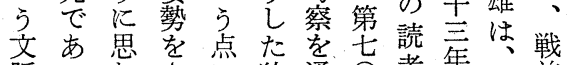

脈つ括さ独通○者年前

をたれらお自じ号関士新に

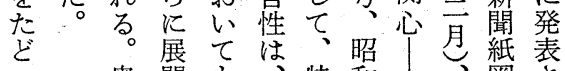

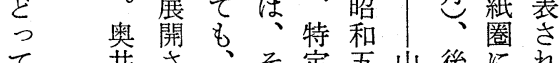

て 井さ、そ定五山後に机

試のせ認この年梨に就た

み都てめで地三県、い新

れ 市ゆら生域月並小林開
る亦に図のにたず作生活究 るはさ世即生れ品活のは い、れ界し活のな史諸 は昭たでた意論ど、相生 、和のあ生識文を生を活 地九でる活、を活活探基 域年あ都実生み用誌究盤 にかっ市態活てしのす 関らたの調感もたいる生 す十。探査覚、うずと活 る一そ究々架奥えれこ体 社年うを文、羊でにろ制 会にし試学明の、もに

調かたみ作確場な密成生 查け姿た品に合し着立活 にて勢のの認にとしし理 言、にで世めはげたた念 及数注あ界ら、ら研をと し度目るをれ伝れ究のい たにし。手る記たででう 論わた生が。的も市枠 文たい活か奥状のり、る組 がっとのり井況で、。み 登て思立と隹や市統こを 登都う的てい活た計引用 さ市奥考、わ史。調たて れ生井察日ばにま查研

て活の㤎常、基た、究目 も圈場、意活域いい学、常
一こる論 マ

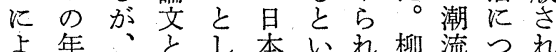

る報全して社えれ思をいて想

$\neg$ 体て、会よ。泟ていの

市教全行

社喜て 金さ年

会多は谷机報

学野、重た司

帮清農義 昭 社

齐に社都学

献 る 会都士心

が典特交年四

、農集通輯

収村と問こは

め社 い題の

ら剖たに特都

て文色 心集市

心献彩て号亯

る。貝釷录が、農

斎々濃收録古

飞、。録市特

よ斎まれ関集

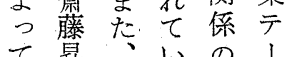

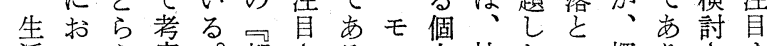
活いえ察。都さるル人社たの探りさす がてたし柳市れ。ガ単会論区究、れる 問はの、田と被ン位体文別さまるな

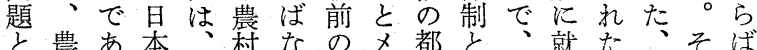
さ農あ本、村なのメ都と都る就た都市い都いる れの。社市朝ま市ンのう市てでるら戦 る問柳会、朝い論の独点、しあ時の前 と題田立農常。見自で村学るにあの こ是常井都解性異落社。洼る都 ろ都場本と講上市をがなを会井、す市 で市合人い講の研紹、る集学上歴の研 のにのう第論究介指の団雑吉史は究 柳問は暮双第妾と利摘で生誌次的、の 田題、方卷がい用さ市活郎な人か のと都しの卷発う寻れり体第郎視口な 都い市と観朝表なる、た、六住野論り 市うはい点朝さらかの契規分つにの多

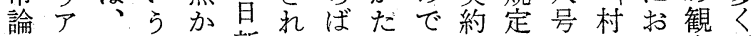
がプ生視ら新た、ちあをしい点が 梌品活野、聞昭柳でっ社た昭らでで社和田て

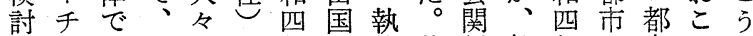
さがあ時のが年男筆井係都年へ市なし れ、っ代生出にのさ上の市十発わた 
は画土院れそて道にるのも十すい十的史こも昭れ作

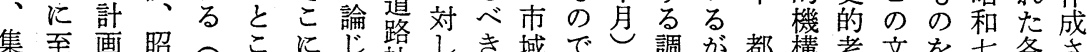

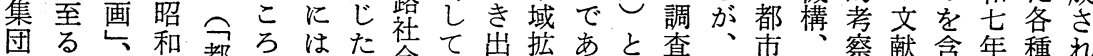

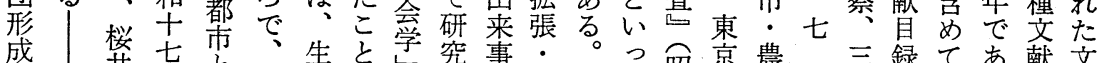

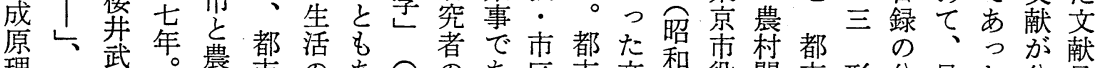
理鈴雄こ霖市のあ今市区市文和役関市形分目た分目

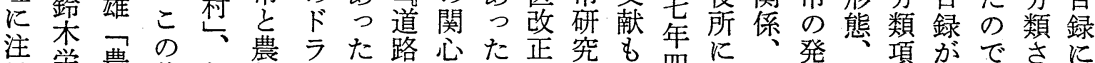

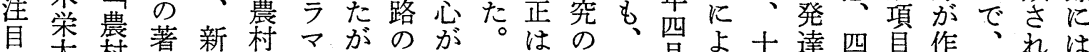

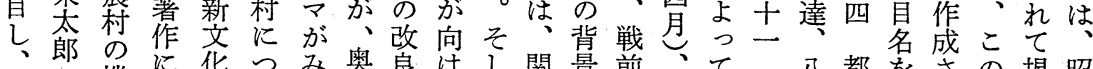
都農機に华つみ奥良けて関景前いて公都をさの揭昭

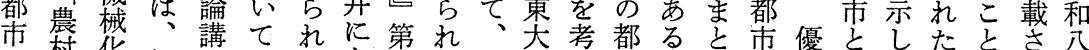

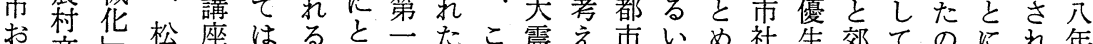

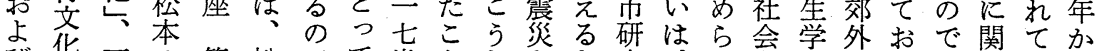
び化石の第松でて巻としなな究记掌的地くあしいら

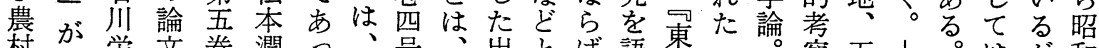

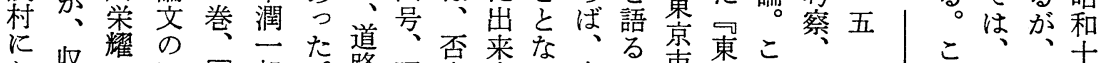

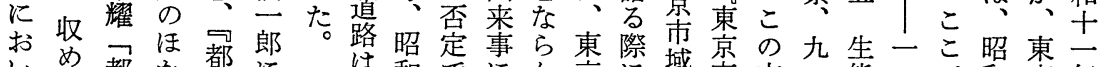

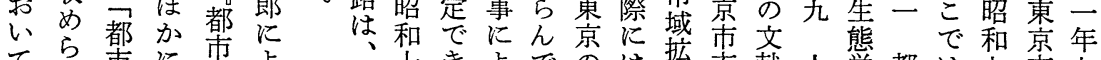

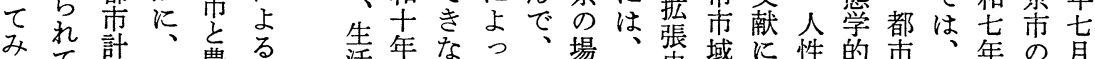
らて婳吉農考活四心てと場見患域飞性的市、年の月

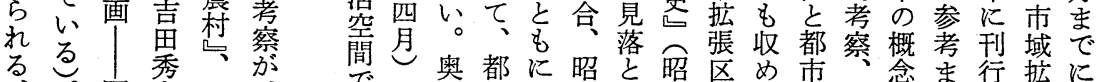

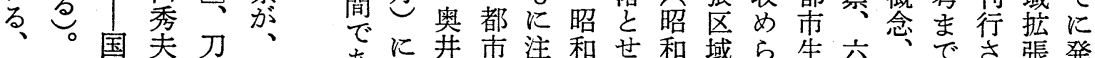
人棼圭国江

の切飞物の式す川と川、指年市らン一预いい上行の 息息生質とでるの題はこ摘、とれシ定琵るてび動接

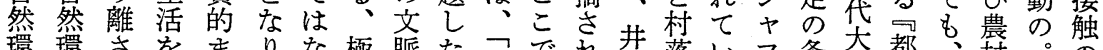

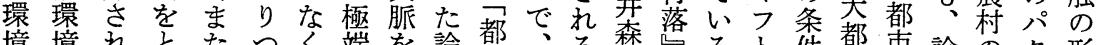

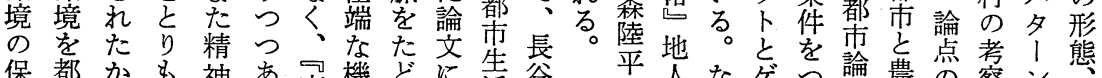
保都かも神あ事機どに活谷 存市たど的り事械るお唀川

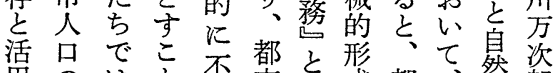

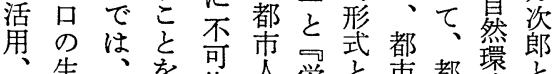
風活々考能吕堂働市市都境高

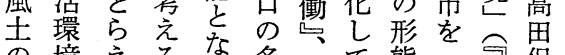
の境えるな多なて態二都保 保と占な数な、都っ都馬

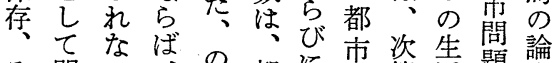

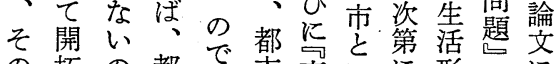
の拓の都で市晾い形第飞 た寺で市るに楽う産態第言 めるあ行る氙形業之艺是 のこ計と政同生の態織て巻て

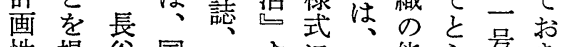
性提谷国二すにコ能方号き が言川家寊るす生率え昭た

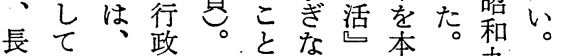
佥い国紫都㤎心の位長杂長 川る家ら市、も様点谷年谷

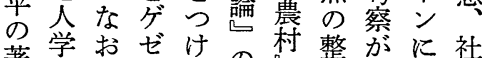
著学社哮たの楚整試に社

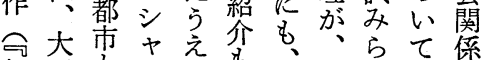

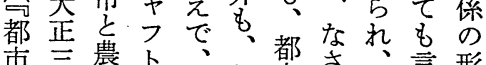
市年農海限打市さ都言形 品年梦飞限さ関孔都是式 霜つめた界な係た市しな 梦田〈゙たが認わ尔で社た

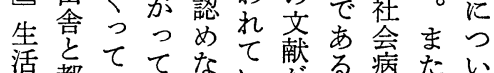

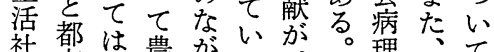

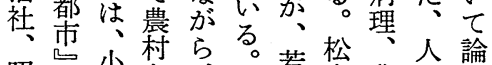
昭少界禁占。若菘農台諭 和江界都テ石干界禁の 九書通市繁菘紹論都筧全間 年院繁比工本介感离妿 な昭冪較五場杂戟化ら生 ぞ和作が合て載な都活

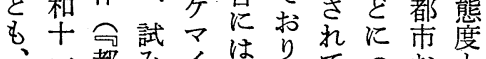


農会とる。策田市るでをの社言のあい生ゼ九杂調土形の明に

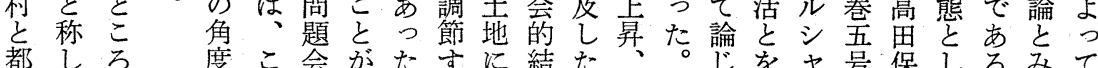

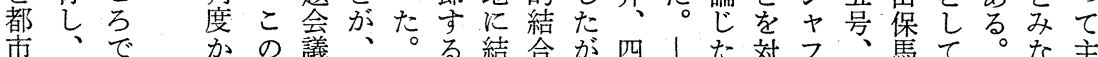

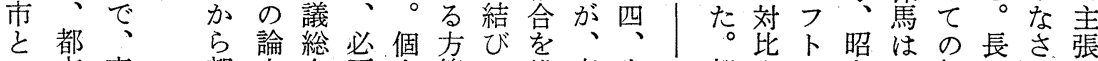
に市高都文会要人策つ維高生二都さに和、都谷机さ 於、田市でにとのをけ持田理、市せな九都市川るれ け村は、問おさ分社たさ自心共生、ら年都がはもをた る落、題隣いれ立会りせ身理同活こっし市構、のの 対を基に保てたを政すたに的社にうてに䦗想都でで 立中礎接組発の階策るりと影会おし、㧤さ市ああ は社社近織表で級とこ、っ響的いた共い関人りりる

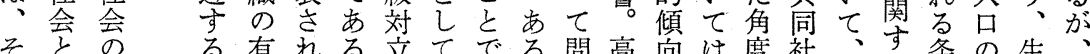

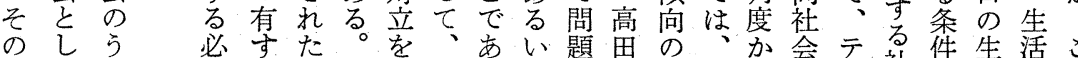
産てち要る研高激国っはとは減次ら的ン社泩活のう 業位でが意究田化家た、な、弱の、な二会つ圈回し の 置 差亏゙国 趩け家 異たを

にが大

よ、社

る 高 会

と.田

こに家

ろ. 族

も机を

あば、 義報のさ的し郷つ都占都農エ学いの復た 究に告こせと、里た市二う市树不的て搪と見 極触にのなべををのへ、な生生の考論大い解 的れよ論いルた持はの競傾萿活挐じにうは にてる文たで、た、人争向のとマ店た注こ

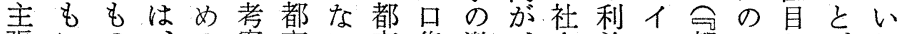
張いの、の案市い市集激、会益ン都でしがわ さるで第方导へ都に中化み学社シ市あて、、将 れがあ四策るの会おに方的会ヤ問るお提

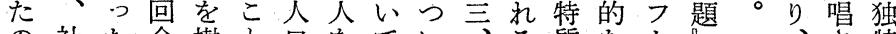
の社た全樹と口をている質なト起、、特 で会。国立な集共共て生の都と第生れの あ政高都すど中同同も活でっ市年一活た文

と道格市考書はれ社関度な人義年今会第る化性益が 呼路: 論察:、ず会係がい化案、井学戦兰のの、を、

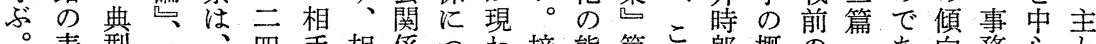
表 型第、四手相係つわ接態第こ郎概の管向向務心之

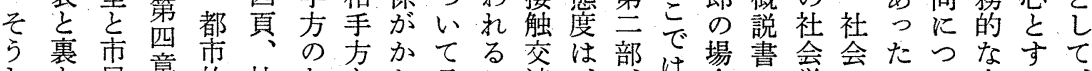
乙主章的社なとた言こ涉部は場書会会たつななすて

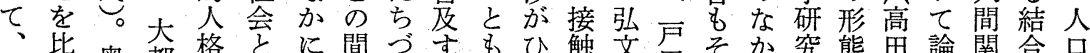

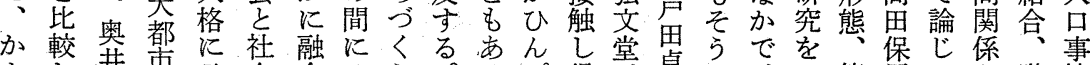

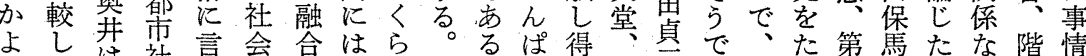

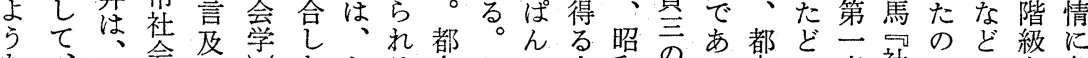

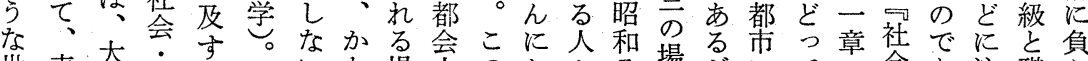

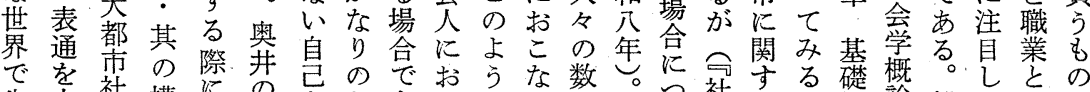

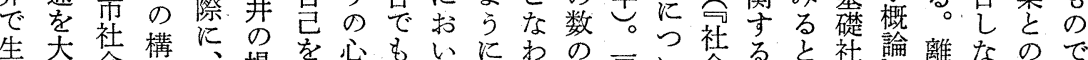

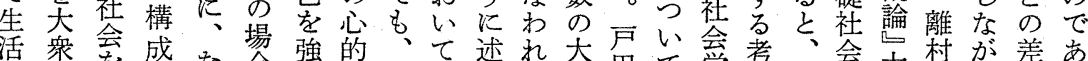

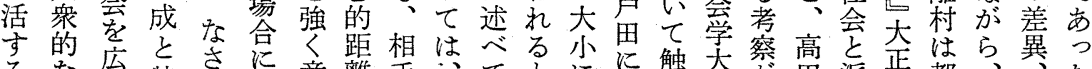

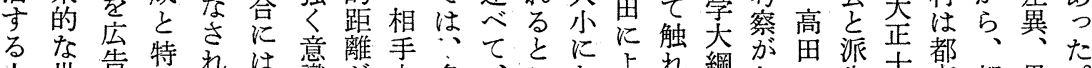

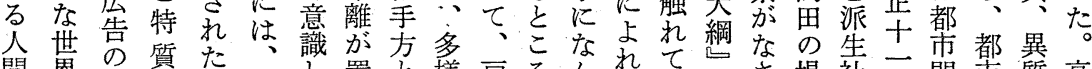

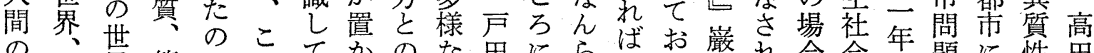

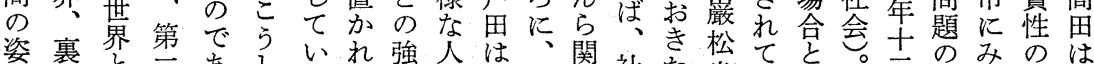

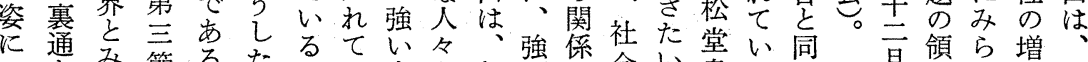

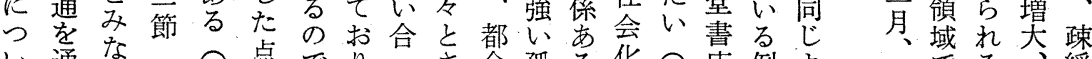
い通な都合点でり吉さ会孤る化こ店例よ岩でる 緩 て人都現にあ、化ま人立むま社市う岩考利顕に も、のを会帒関る都はざの化のた会昭あに、波察益著し

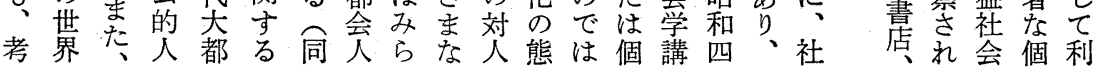


娛は社豊る いの造に認し揭昇なっ昭形然程 军察

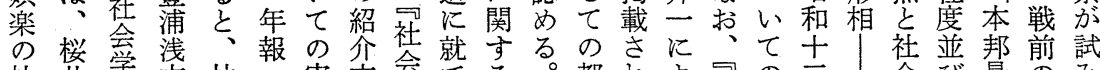

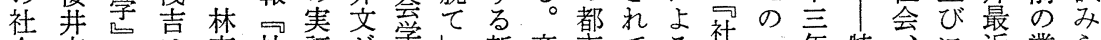
会庄第は恵社証が学し新斎市てる社一年特会に近業ら

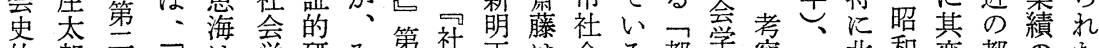
的郎輯東枆学研み第社正は会る都学察渡北和変都のた

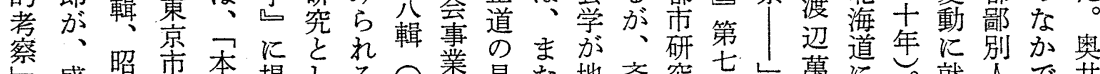
に盛和の邦揭しる。昭研盼た地斎究七輯萬に就人で井 にり九死内載て、和究解、域藤最輯同寿於まい口はの

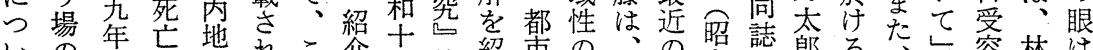

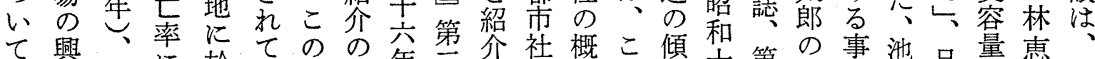

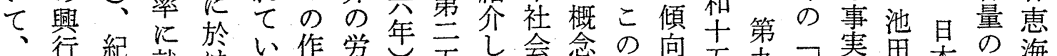
ま物元就ける品をの券て学を記と吾杂都害畋本研海間

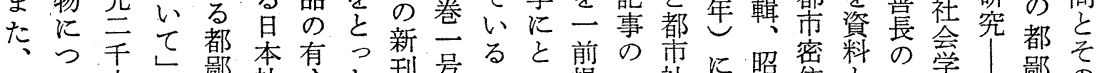

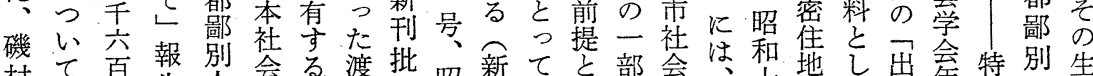
村て 百告人会る 渡批昭新てと部会和地し出会特別生

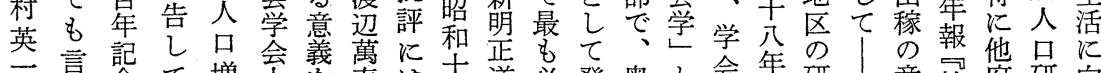
は及念て堌合毒は士道必発奥々会年研|意社府研向

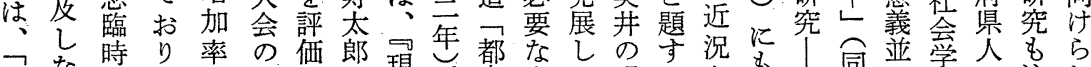

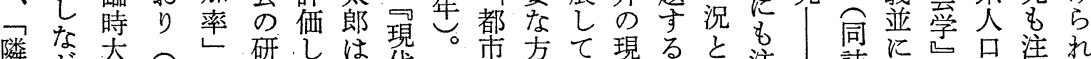

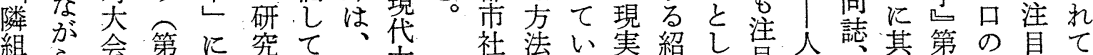

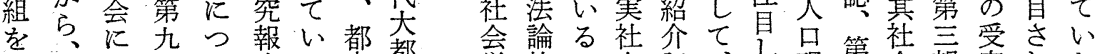

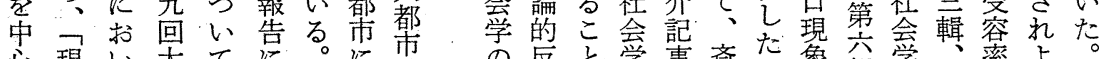

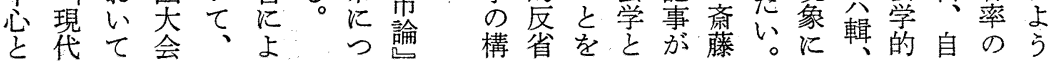

研 代 三本

究会宅宣都

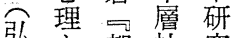

弘立都社究

竞現市会史

畫袋研合構

房奛究治想

大兄治守

正弘奉士る

三吝業三年

年賞早年

、畫本社妾

柳大社齐势

田企明館国

男分告昭場

都年士惒合

市山年四は

農正米年横

村可岩山

朝亲庄波源

新活郎庵助

聞の現、日
第治正の大こ会研潮雑正制種空会のす 五主都正う会究誌士度の論題に動る

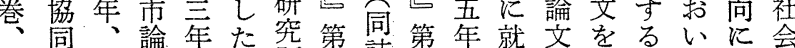
中的都をこ情題第誌交艺心のた報て就意 央精嘟見二報貝巻第三清て、ほど告はて識

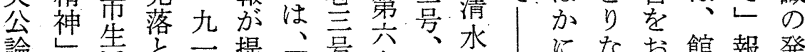
諭活さ四提都号杂昭照上飞な挑館登 社新のさ四供都号号和男へ古らこ稳告展 昭少家い年さ市昰昭四の星谷都っがしに 和説族よかてで士和年竝社善市て都いつ

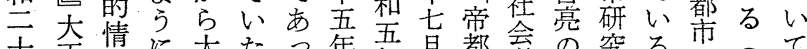
四正緒に昰こたっ年年永都拿の究る。のへて

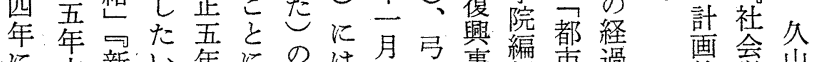

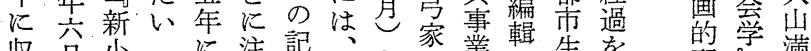
収公少乞に注記、な家業輯生を配学満

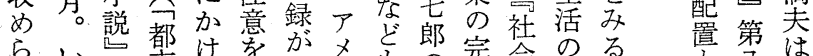

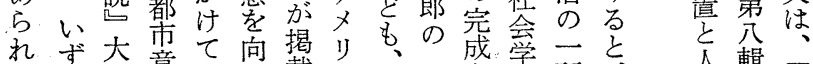

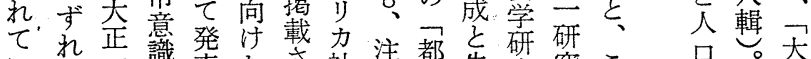

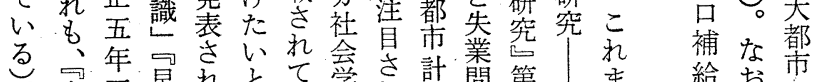
大五早れ鲁い会れ画題一特で地尔に 山月畄た思る第る。運題巻特に域第於

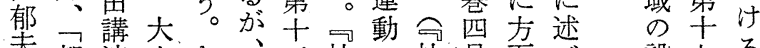
夫全都演山な当㟔社の社号面心゙設七る 全市兄郁挍当回会新会、委た定回娱

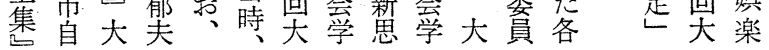




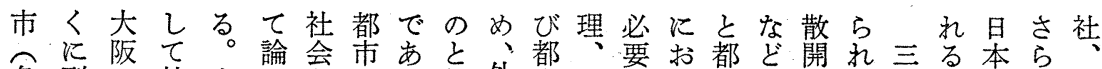

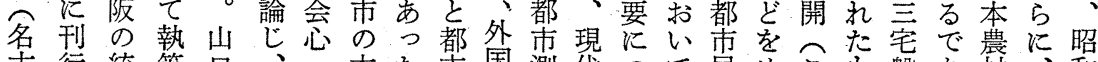
古行統筆口、、本た市国測代つて民ぬこも磐あ村、和 屋さ計さのさ都質。生の量大いはのぐこの学夸問邱四 市机資れ著ら市: 米活研な都て、自つでで著う題致年 て料た作にの人田者究ど市述都賞てはあ作。研中心

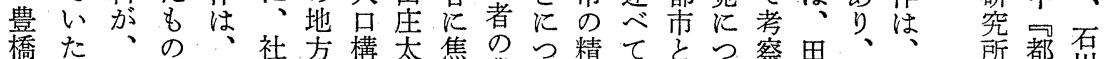

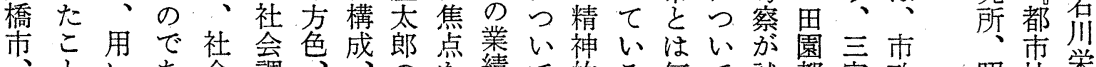

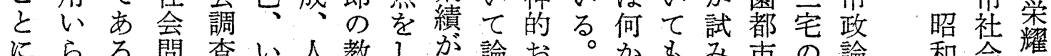
岡にらる問查い人教しが論お。方もみ市の論、和会耀

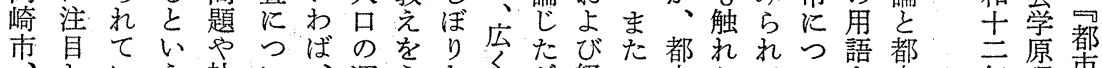
市しいえ社いは運うな活が経米市らてい都梧都市原都

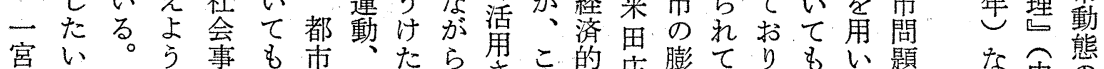

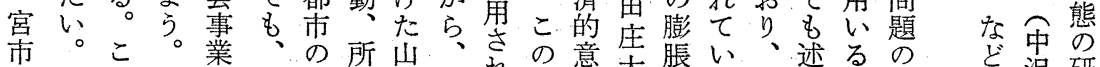

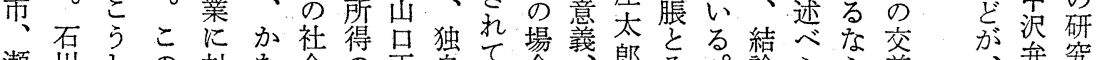
瀬川 户栄た著すり志構 市耀山作る、詳理成、文る。代、趨宅沶て、る 要郎刀

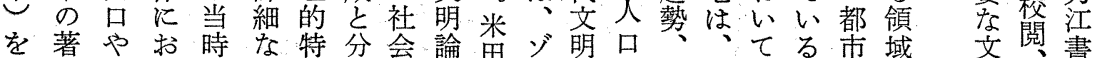

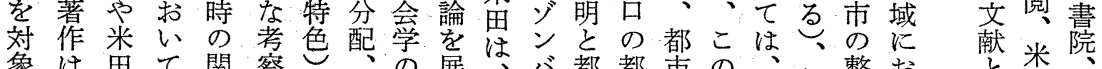

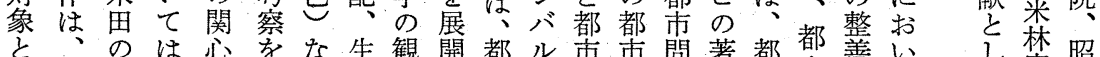

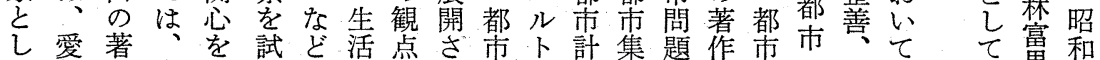
て知作東背み、問吕せそを画中研ののの都ま指男确七

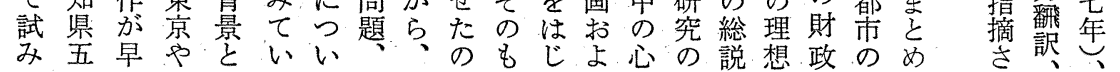

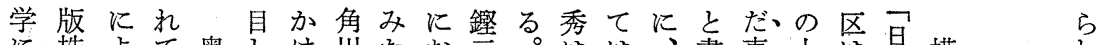
に株よて奥しけ川たお言。はは、書東上は星横的

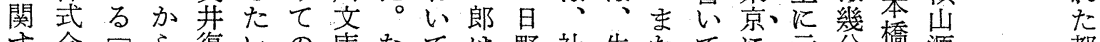

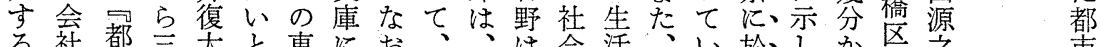

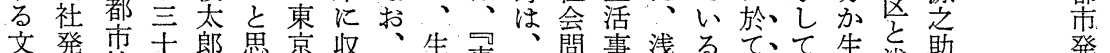

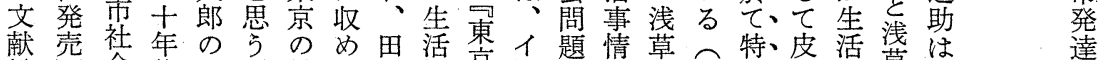

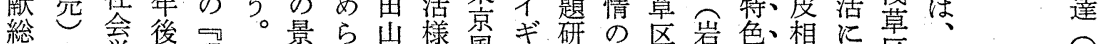

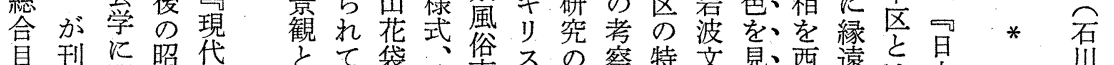

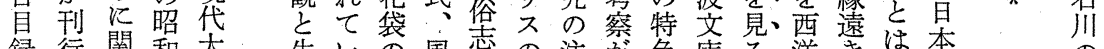

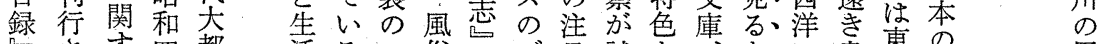

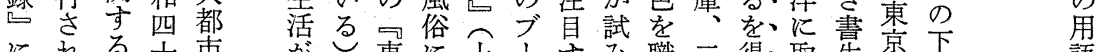
にれる十市㤎東に上、寺み職三得取星京下 よた文五諭、を京注巻スべら人士心゙り、市層

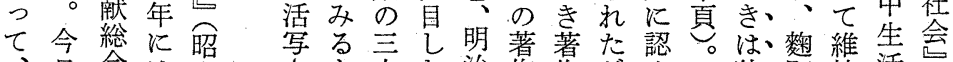

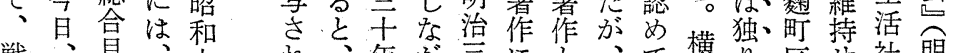
戦、目、十、年がにと、て横独、区世社奛

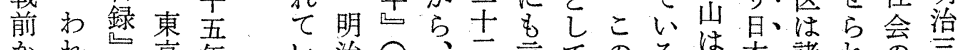
加れ京年 心治犬言言てのるは本諸れ会 らわ学都、る十正山年是、作。日橋管、中士

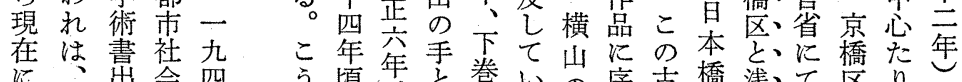
飞、出会四 いこ版学 ○ たの会研年 る可刊究 都・都、会 市市綮会出 研社学編版 究会出集さ

し分博下明る作を典区草、維は、の た文妾町治。品奇的の薄持性神節 献正館比文たを評た作色に、ら質田に

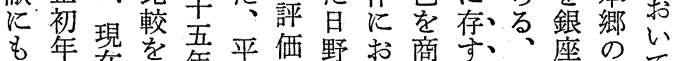
注年在試年出哲資い㒀守、唯通両て 
正な論都るう会よ理と研あからめあょ市総れらら業の

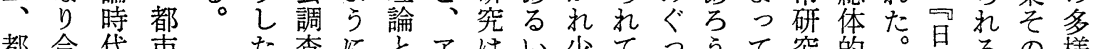
都合代市た查にとアはい少てっうて究的。本るの様

市 い、研

の が 都 究

行み市史

政 ら社 は

员会拿

政よ時 并

う代の

社にの場

会思四合

事わ段に

業犯階任

々る。文 文

つ都 分 明

た市さ評

実のれ論

際 施 た時

的設落代

な公こ市

題㗆 曋政

問業時時

題市 代

の 区の経
調にもいメ、はなきて。導はにこ本をでもな

查対なうりこ斿た、まか、都れ市の流 のすう点力う文れの人たれ社市ま履ろにれ

分るたににし明、で口、る会問で盧うよと 野関。おおた論都あ現都か問題の社。う研 に心社いけ角的市る象市た題を考会て究 おが会てる度にを。研へち, 軸察は方の

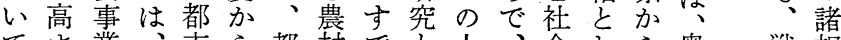
てま業、市ら都村でと人、会しら奥、戦相 、りやや研試市とにい口沶事ても井後を 都、社が究み研い指う集こ業な明ののの展 市さ会てのら究う摘ス中なをしら著都望 研を問、動れを文し夕、わ背とか作市守 究ざ題人向たお脈たイ都れ景げでが研る がまと間がだこをよル市てとらあ出究こ 展なの生紹けな考うで膨きしれる版のと 望調密態介でつ慮に都脹たててがさ進が さ査接学さはてし、市、と、き、れ展で れがなのれなきないに過考市たわるるとき た、関影、かたがず関大え政のが約研る こお連響都つのられす都る論で国四究 とこ性が市たで、のる市ことあの十のこ

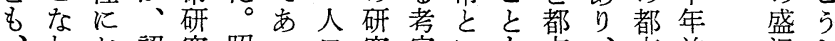
わお認究昭っ 口究察い母市、市前況乙 注れいめの和た論者がうで計戦研に閏きが 貝たて、ら方に。的も、問き画前究刊、編 れそ社るとる市、多みを証都ささ倳
大はれる制画流てのっい五れ磯士済

都都す る

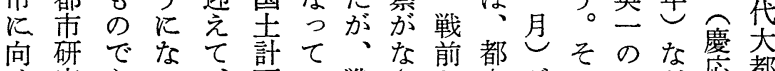
け究あっ、画い戦さ加市がのコど虑都 ら者つたかにた時れら研、数区が出市 れのた。よみと中て町究出年の、版論 て関々戦 うらいにい内版後研刊社出 い心い前なれえおた会枠さに究行昭出

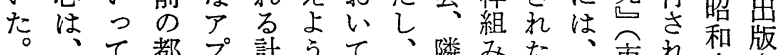

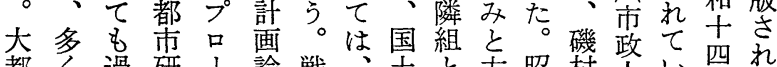

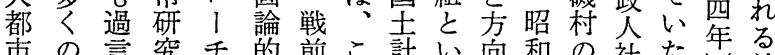
市の言究手的前こ計い向和の社た年る

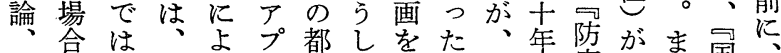
都合な人古市ため地か代空出た国

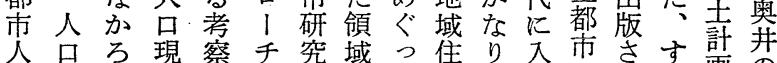
人吕ろ現察チ究域っ售り明乃の市さす婳の 論都。研、壬一研む組確と研てに諭著 之市ま究二見つ究各織に、究い:作

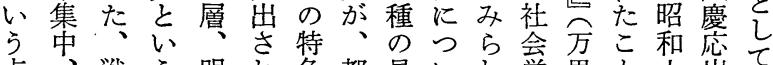
点、戦う明れ色都見いれ学里と十出は

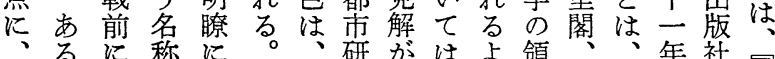

戦いお妳み戦都究示幾う域昭注に都 前はい呼ら時市のさつにに和貝は昭市
ろイれがる展察 うブる認。開 がわめ戦があ 注けら前みる 目でれのらい さはる都れは れなよ市た るいう研の解 よがに究で決 う、思にあ に住わはり、方 な民れ、向 つへる市各う たの。政種け の接もの的 は近ち側都 い 戦之弓 名市ら 戦住ん占論と 集民方垫 このう向、に と側乙性発㧤 でかたと表い あら傾パさて るの向、れ とパだスて都 考、けペき䒾 えスがクたの てペ指テの研 よク摘ィで究 かテさブあの 
日のな学しすめじ批道業あれ点たで研現ざてか都 奥本よいはてるにた判の社績りどに、発究象る充ら市 井のうも、新し論会と、も扫表をにを実み研 は都にの都注こエ萠た文会し戦、い市さお向得しる究 、市うで市目れコはも業て前今て研れこけなたなの

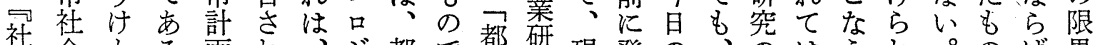

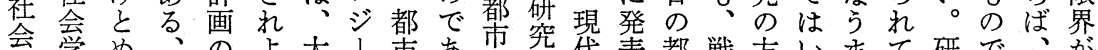
会学め、のよ大 事をれと哲う胆の社つ社会にさ市前法たでお究は調、

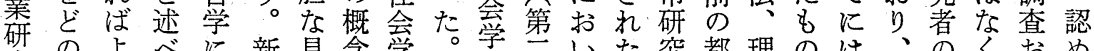
究のよべに新見念学。学三いた究都理のは、のくおめ 旮よいたな明解やの都構五て論の市論の、都眼、よら うの㔔りはで方進市構巻も文基研的、い市は出びれ 第にで、得、亦法路社造然、基究枠着た問、発理る 三語あ今る現る学会就号十公はの組実ら題いし論で 五る万日音在が放都学就、分刊、水みななのおた化あ 巻こう、、の、董市はこ昭にさこ準の都か追ばばのろ

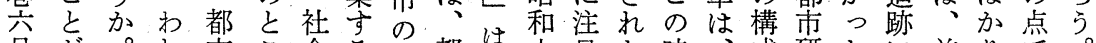
号が。れ市こ会る構都は士貝た時成研たに前りで。

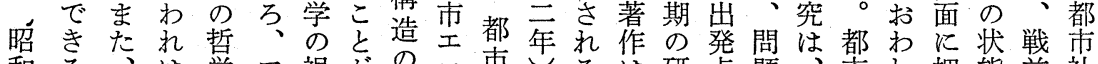
和る、は学ア視がのコ市しる保点題、市れ押態前社 十の現、とメ野必探口研にで、究の点ま論てしをの会 三で在こはリを要究湥揭あいに状のこはい出示都の 年㐫、うな力確でに!の载らす見況整々、てさし市研 ろわしる流認市求で現さう。出に理に多、れて研究 にうれたこの方るめな状れ。もさあの少様緻てい究と 方市見と都る、、いをた 社。机解の市主とそ、嚴新

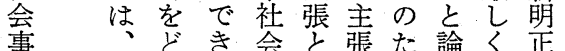

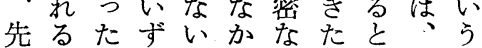
駆の。れ。た事都言決角 的でけのまち例市わし度

落学調のはれ拓れ地のに問とりる究た究るこ社の業 研、查進最伊たさる域都打題に、も者いと合会地文

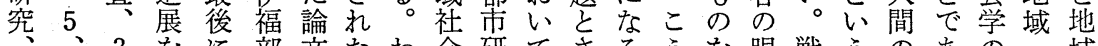
7 人 $3 、$ を部文たわ会研てさろらを眼戦うのあの の 域 、間都待幾輝ほ地わ論究も杂う。探に前観研る課地社 都生市しつ加を生はさこ戦点す目都かで、と学 市態研たか倉にさは活、らと前かるし市らあそ考みし 社学究いの过もら、意いにものら姿た研、っのえらと 会 文都問平、にそ識わ発あ都も勢心究奥た都たれ題 学都都思題治な豊う論ば展つ市、柱をを并。市。るし

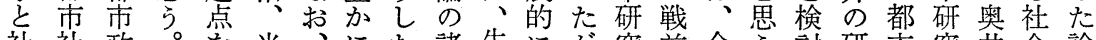
社社政。を米、にた諸生にが究前今う討研市究井会論 会会策 1 、指林注耕ル領活継、にの日。す究生はの性文 学学、都都富貝作 I 域環承そお都に旦るの活、都社を 6、市市て、なるて、通論れでて研い生持現者地市会寄

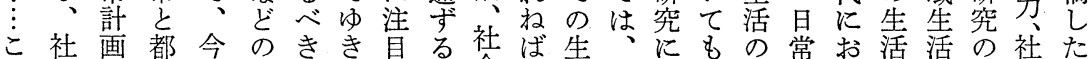

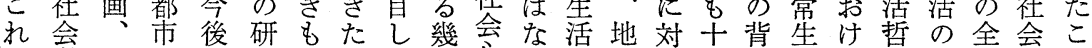
ら学 4 、現の究のいなる出ら研域し分景活る学研体関々

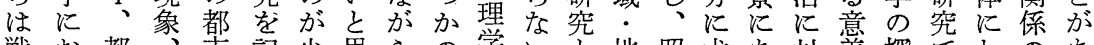
戦沶都、市記少思らの学いと地照求市対義探でわの市

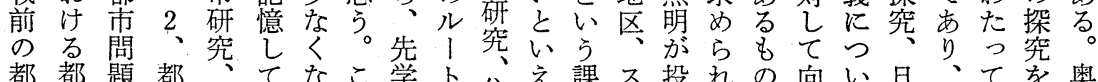

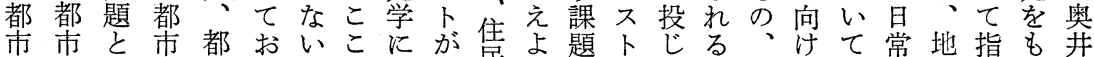
研研都の市き。でよ、組う。は、らも基ら考生域摘っは 究究市理社たこ紹つ見織。、1れの底れえ活にさて にと社論会いこ仝て出織戦現卜るでにたてのおおれ地特 お村会と学。でさ開さ論前代がこああ研み研ける域定 


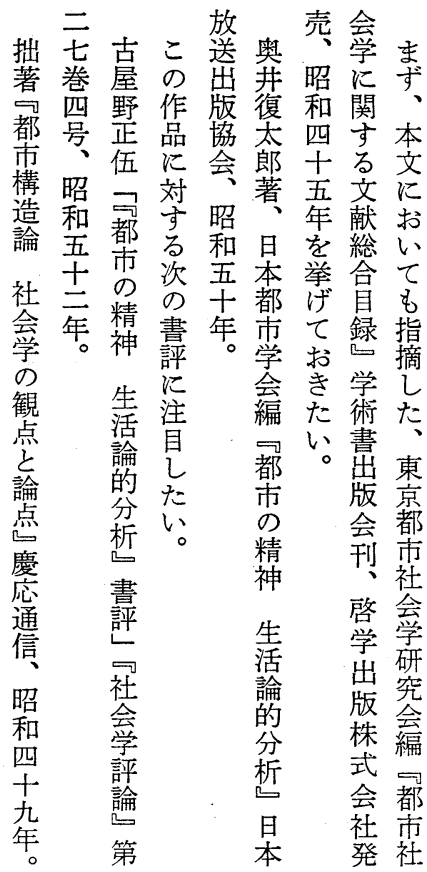

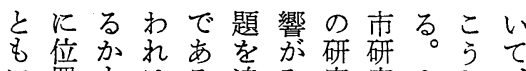
に置もはろ追み究究まし、 うし、ううらををたた本 文日けれ数かたれ、試争来 常らな々。。な不み歴点で

献れいの社都か徹る史は市

献活る。都会市っ底姿的氺 のこけ市学社たで勢な不ば なとれ研の会とあが視鮮 かはど究研学は心っ、野明争 、明、知名名光前、な点

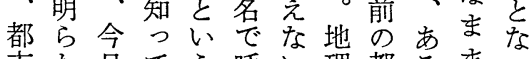
市か日てう呼い理都るまう とでのい視ばが学市いにた 人あ都る野れ、や研は放は 間万市。はる研歴究社置ず にう社そ、研究更㳂さの つ。会れ不究者学は体れも い先学ら明がはの、制ての て学研の瞭、、都欠をしで 考の究多でど大市け考まあ え研がくはれ都研て慮っる た究、はあほ市究いしたが いにそ、っど現かたたよ、 と注れ都たみ象ら。うう実 思目ら市がらと受地えに際 うすの論、れ都け方で思に る延でわた市た都、教 と長あれの問影市都れ

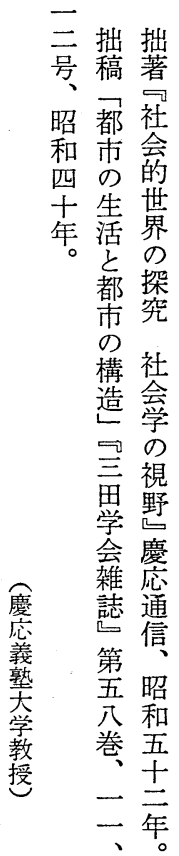


yet there has been not a little remarkable works in this field and some of which was published in pre-wartime. Although from the sociological point of view there were scarcely proper studies on urban phenomena in pre-wartime, we must remember that Fukutarō Okui's "Essays on Contemporary Metropolitan Cities" was published in 1940 and this work was first intensive sociological study of urban society and of urban way of life.

Generally speaking Okui's early works may be called studies on social problems and social thought. The sources and spirit of his sociological studies on urban life may be resumed as follows: (1) John Ruskin's spirit, (2) Forms and spirit of European medieval cities, (3) theory and method of urban studies in America, (4) sociological and ecological researches into Tokyō and Kamakura, (5) urban life sketched out in Japanese novels and essays, and (6) his own everydays experience.

Now urban studies in pre-wartime may be classified into next five streams : (1) essays on urban or rural-urban problems, (2) on social problems and social work, (3) on municipal government, (4) on urban population, and (5) on town planning.

Tracing these various streams, much of these are mainly characterized by demographic or statistical approach and also by orientation toward (rural-) urban or social problems.

Through these theoretical or empirical surveys of urban phenomena, not only various phases of everyday life but also structure of urban social world were clearly clarified.

Urban studies in pre-wartime are primitive in its method and can be regarded as proto-type of sociological study of urban society, but today we must pay attention to these works because of its some viewpoint, perspectives, and problem-solving approaches.

\title{
On the Formation about Sociology of Labour and Industry in Pre-war Japan
}

\author{
Tetsuji Fuse \\ Hajime Kobayashi \\ Hokkaido University
}

It is commonly accepted that sociology of labour and industry in Japan had begun by Kunio Odaka on his study about professional sociology (1941). 


\title{
Japanese Rural Sociology before World War II
}

Suzuki's theory and Ariga's theory —-

\author{
Kazuo Goto \\ Nara Women's University
}

From 1920's to early 1940's Japanese rural sociology were gradually coming into existence as special sociology with two systematic theories. The two theories were Eitarô Suzuki's 'Shizenson' theory' and Kizaemon Ariga's 'Ie-rengō' theory which was mainly researching on 'Dōzoku' group. This paper is to discuss how the two theories were influenced in the formative process by agricultural policy, folklore, and American rural sociology, and it is also to deal with what characteristics they came to possess as a result of the influence.

Summing up, Suzuki and Ariga were alikg in trying to investigate the structure of Japanese rural society with the key concepts of their own inventions. While Suzuki's 'shizenson' theory, whose method accepted the influence of American rural sociology, was chiefly founded on the facts in the rural society in the southwestern part of Japan, on the other hand Ariga's 'Ie-rengo' theory, under the enormous influence of folklore, was based upon the study of 'Dōzoku' group which had often been observed in the rural society in the northeastern part of Japan, and it was the theory generalizing the hierachal pattern in social relation, admitting that it was true of the social character of Japanese people.

\section{Urban Studies in Pre-wartime}

\section{Takeshi Yamagishi Keio University}

Urban sociology is a science which surveys everyday life in urban areas and neighboring districts.

One may say that in Japan there has been no tradition of sociological studies on urban life or society. Somewhat we cannot but agree to this idea, 